BMJ Paediatrics Open

\section{Psychological Concerns of Children Undergoing Kidney Transplantation During the Pandemic: Single- centre Experience}

To cite: Paessler A, Boyle S, Marks S, et al. Psychological Concerns of Children Undergoing Kidney Transplantation During the Pandemic: Single-centre Experience. BMJ Paediatrics Open 2021;5:e001174. doi:10.1136/ bmjpo-2021-001174

- Additional supplemental material is published online only. To view, please visit the journal online (http://dx.doi.org/ 10.1136/bmjpo-2021-001174).

Received 26 May 2021 Accepted 12 July 2021

D Check for updates

(C) Author(s) (or their employer(s)) 2021. Re-use permitted under CC BY-NC. No commercial re-use. See rights and permissions. Published by BMJ.

${ }^{1}$ University College London Great Ormond Street Institute of Child Health Library, London, UK ${ }^{2}$ Paediatric Nephrology, Great Ormond Street Hospital For Children NHS Foundation Trust, London, UK

${ }^{3} \mathrm{NIHR}$ Great Ormond Street Hospital Biomedical Research Centre, London, UK

${ }^{4}$ Transplantation, Guy's and Saint Thomas' NHS Foundation Trust, London, UK

Correspondence to Miss Alicia Paessler; alicia. paessler.20@ucl.ac.uk

\section{ABSTRACT}

Many paediatric kidney transplant programmes were closed during the COVID-19 pandemic, and due to the vulnerable nature of patients with end-stage kidney disease (ESKD), there were new concerns once these programmes reopened. We surveyed children and families who received a kidney transplant during the pandemic. We found that half of the participants felt scared and/ or anxious about receiving a kidney transplant during the pandemic, and 2/8 participants were worried about catching COVID-19 during their recovery. While detailed counselling and additional safety precautions contributed to a good experience, patients and parents still demonstrated fear towards transplantation.

\section{INTRODUCTION}

The COVID-19 pandemic has brought a lot of anxieties for patients with end-stage kidney disease (ESKD), particularly as they were identified as a clinically vulnerable group. Many transplant programmes closed and reopening brought new concerns for patients and professionals. We report patient and parent experience on receiving a kidney transplant during childhood in our centre during the pandemic.

\section{METHODS}

In the first 6 months of reopening our transplant programme, 13 paediatric patients received a kidney transplant. One family refused the transplant due to significant fear around the COVID-19 pandemic, uncertainty and the risks that the pandemic entailed with regards to transplantation. To be eligible for this study, participants had to be transplanted at our centre during the pandemic and have completed the 3-month post-transplant shielding period. Shielding refers to not having any contact with people outside of one's household and staying at home as much as possible. An anonymous questionnaire was developed with patients and our wider team members including family therapists and psychologists and then sent to all patients and families who were eligible to participate. See online supplemental file 1 .

\section{RESULTS}

Some of the additional safety precautions implemented as part of our new standard of operating procedures included shielding periods before and after the transplant, specific pathways for admitting patients to the ward, staff wearing PPE and SARS-CoV-2 PCR DNA testing prior to admission. Patients and families were informed of these precautions and received counselling about how the pandemic might impact their transplant experience and the risks that SARS-CoV-2 poses on immunosuppressed children based on latest published evidence. Of the 13 patients transplanted during the pandemic, 10 were eligible to participate and eight participated by completing the questionnaire. Study participants included four parents responding on behalf of children under 12 years old, and four children over the age of 12 years who were encouraged to complete the questionnaire themselves. Five patients received a living donor kidney transplant and three patients received a deceased donor kidney transplant. All transplanted patients felt that their questions were answered before the transplant and $6 / 8$ felt well informed about SARS-CoV-2 and the effects it may have on transplantation. The majority of participants reported surgical complications being their biggest fear; and two participants were worried about catching SARS-CoV-2. Other concerns mentioned were regarding the recovery time and having to spend time away from loved ones. Participants' feelings prior 
Feelings About Being Transplanted During the Pandemic

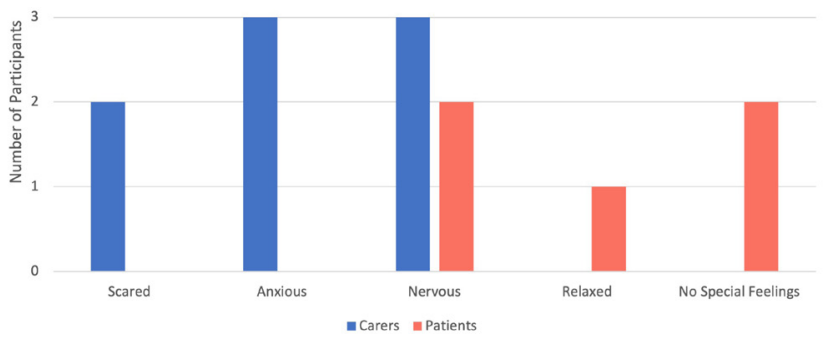

Figure 1 Feelings of patients and carers before the kidney transplant during the pandemic.

to receiving a kidney transplant during the pandemic are seen in figure 1.

Seven participants felt that care was delivered safely in inpatient and outpatient settings. One participant mentioned 'We felt vulnerable during the walk to and from the hospital'. 6/8 participants found shielding easy before the transplant and this increased to $7 / 8$ after the transplant. Overall, $7 / 8$ patients were glad to have received a kidney transplant during the pandemic. The patient who was not glad to have received a kidney transplant during the pandemic commented: 'It has been so hard because after being so ill and dialysis I was not able to go anywhere or see anyone once I felt well'. This shows some of the difficulties that patients faced after being transplanted during the pandemic.

\section{DISCUSSION}

Receiving a kidney transplant can be a stressful experience, particularly during a pandemic. However, as transplantation is the preferred treatment for children with ESKD, ${ }^{1}$ it is essential that renal transplantation programmes remain open where possible. Our results show that the pandemic has had a significant impact on children and families with ESKD, with patients and families reporting feeling significant fear, despite detailed counselling about the risks and addressing their concerns related to SARS-CoV-2. Children who undergo extended periods of isolation are more likely to experience depression and anxiety, ${ }^{2}$ so it is essential to provide this group of patients with additional psychological support, ${ }^{3}$ ideally starting prior to the transplant. Psychosocial support is standard in many paediatric transplant programmes regardless of the pandemic but based on results of our patient survey, transplant centres might want to consider enhanced support during and after the pandemic. Further multicentre collaborative studies could add validity to our findings, help define the size of the problem, determine what additional support is required to reduce patient fears and concerns and what the long-term effects of the pandemic are on this vulnerable group of patients.

\section{Twitter Alicia Paessler @AliciaPaessler}

Acknowledgements We would like to thank the patients and families for taking the time to participate in this study and sharing their experiences. We would also like to thank the healthcare professionals at Great Ormond Street Hospital for Children NHS Foundation Trust for their hard work in ensuring safe experiences for all patients and their families.

Contributors Patient and family were involved in the initiation and design of the study. SB and JS coordinated methodology and data collection. AP conducted the analysis of the results, wrote the initial draft and coordinated the submission of the manuscript. SB, SM, NK and JS reviewed the manuscript.

Funding The authors have not declared a specific grant for this research from any funding agency in the public, commercial or not-for-profit sectors.

Disclaimer The views expressed are those of the authors and not necessarily of the NHS, Great Ormond Street Hospital for Children NHS Foundation Trust or the Department of Health.

\section{Competing interests None declared.}

Patient and public involvement statement One paediatric patient and his family were involved in the initiation and design of the study. Patients and the public were not involved in the conduct, reporting or dissemination of the study results.

Patient consent for publication Not required.

Ethics approval Patient consent for publication was not required. This project was registered with the Great Ormond Street Hospital for Children NHS Foundation Trust Research and Audit Department (Reg \#3030).

Provenance and peer review Not commissioned; externally peer reviewed.

Supplemental material This content has been supplied by the author(s). It has not been vetted by BMJ Publishing Group Limited (BMJ) and may not have been peer-reviewed. Any opinions or recommendations discussed are solely those of the author(s) and are not endorsed by BMJ. BMJ disclaims all liability and responsibility arising from any reliance placed on the content. Where the content includes any translated material, BMJ does not warrant the accuracy and reliability of the translations (including but not limited to local regulations, clinical guidelines, terminology, drug names and drug dosages), and is not responsible for any error and/or omissions arising from translation and adaptation or otherwise.

Open access This is an open access article distributed in accordance with the Creative Commons Attribution Non Commercial (CC BY-NC 4.0) license, which permits others to distribute, remix, adapt, build upon this work non-commercially, and license their derivative works on different terms, provided the original work is properly cited, appropriate credit is given, any changes made indicated, and the use is non-commercial. See: http://creativecommons.org/licenses/by-nc/4.0/.

\section{ORCID iD}

Alicia Paessler http://orcid.org/0000-0003-3891-904X

\section{REFERENCES}

1 Winterberg PD, Garro R. Long-term outcomes of kidney transplantation in children. Pediatr Clin North Am 2019;66:269-80.

2 Loades ME, Chatburn E, Higson-Sweeney N, et al. Rapid systematic review: the impact of social isolation and loneliness on the mental health of children and adolescents in the context of covid-19. J Am Acad Child Adolesc Psychiatry 2020;59:1218-39.

3 Flannery H, Portnoy S, Daniildi X, et al. Keeping young people connected during COVID-19: the role of online groups. Arch Dis Child 202110.1136/archdischild-2020-320222. [Epub ahead of print: $17 \mathrm{Feb}$ 2021]. 